\title{
A prospective investigation of injury incidence and risk factors among army recruits in combat engineer training
}

\author{
Joseph J Knapik ${ }^{1 *}$, Bria Graham², Jacketta Cobbs ${ }^{3}$, Diane Thompson ${ }^{4}$, Ryan Steelman ${ }^{1}$ and Bruce H Jones ${ }^{1}$
}

\begin{abstract}
Background: United States Army combat engineer (ENG) training is an intense 14-week course designed to introduce new recruits to basic soldiering activities, Army values and lifestyle, and engineering skills and knowledge. The present investigation examined injury rates and injury risk factors in ENG training.

Methods: At the start of their training, 1,633 male ENG recruits were administered a questionnaire containing items on date of birth, height, weight, tobacco use, prior physical activity, and injury history. Injuries during training were obtained from electronic medical records and the training units provided data on student graduation and attrition. Risk factors were identified using Cox regression.

Results: Ninety-two percent of the recruits successfully graduated from the course and $47 \%$ of the recruits experienced one or more injuries during training. Univariate Cox regression demonstrated that recruits were at higher injury risk if they reported that they were older, had a higher or lower body mass index, had smoked in the past, had performed less exercise (aerobic or muscle strength) or sports prior to ENG training, had experienced a previous time-loss lower limb injury (especially if they had not totally recovered from that injury), or had a lower educational level.

Conclusions: The present investigation was the first to identify injury rates and identify specific factors increasing injury risk during ENG training. The identified risk factors provide a basis for recommending future prevention strategies.
\end{abstract}

Keywords: Age, Body mass index, Smoking, Exercise, Physical activity, Prior injury, Education

\section{Background}

The United States (US) Army Combat Engineer (ENG) course is a physically intense, 14-week course designed to develop basic soldiering skills, introduce Army values and lifestyle, and impart engineering knowledge and skills that are used in combat operations. The first 10 weeks of training involves basic soldiering and the recruit is very active with almost daily physical training (exercise) in addition to periodic road marches, obstacle course negotiation, marksmanship training, drill and ceremony, high tower operations, team and individual movement exercises, land navigation, and other physical

\footnotetext{
* Correspondence: joseph.knapik@us.army.mil

'US Army Institute of Public Health, Epidemiology and Disease Surveillance Portfolio, ATTN: MCHB-IP-DI, 5158 Blackhawk Rd, Aberdeen Proving Ground, MD 21010, USA

Full list of author information is available at the end of the article
}

activities. The latter weeks are devoted to training more specific to combat engineering. Physical training continues and other activities include operation of heavy equipment, construction of fighting positions, erection of obstacles and defensive positions, placement and detonation of explosives, route clearance of obstacles, use of fixed or floating bridges, preparation and installation of firing systems for demolition and explosives, and training in techniques to detect mines either visually or with mine detectors.

A number of previous studies have examined injury rates in Basic Combat Training (BCT) [1-5] and infantry one-station unit training (OSUT) [6] and we recently examined injury rates and injury risk factors in military police (MP) OSUT [7]. In this latter investigation we demonstrated that male recruits were at higher injury 
risk if they were older, had smoked in the past, had performed less frequent exercise or sports prior to MP training or had a prior injury [7]. Identifying injury risk factors in military training provides a basis for recommending future prevention strategies. The activities involved in the diverse types of military training may put personnel at different injury risks and thus it is important to investigate each type of training separately. The purpose of the present investigation was to examine injury rates and injury risk factors in ENG OSUT training.

\section{Methods}

Participants were 1,633 men participating in ENG OSUT at Fort Leonard Wood, Missouri. These recruits were from 11 separate training companies in two battalions that began training between 9 August 2010 and 14 March 2011 and completed training between 19 November 2010 and 24 June 2011. None of the ENG OSUT companies involved in "Exodus" were included. Exodus was a two-week period over the late December and early January period when no training was conducted and the recruits were allowed to return to their homes. Ethical approval for the study was granted by Human Subjects Protection Office at the US Army Institute of Public Health [8] which follows the Helsinki Declaration on Ethical Principles for Medical Research Involving Human Subjects. An anonymised database was used for the analyses.

\section{Procedures}

Recruits completed a lifestyle questionnaire within the first week of training. This questionnaire contained items on date of birth, height, weight, tobacco use, prior physical activity, and prior injury history. Recruit demographic data were obtained from the Defense Manpower Data Center (DMDC). The DMDC systematically collects and maintains an archive of military manpower, personnel, and training data to support military information management needs. Demographic information obtained from the DMDC for this investigation included component (active, reserve, National Guard), educational level, marital status, and race.

Recruit injuries were obtained from the Defense Medical Surveillance System (DMSS) of the Armed Forces Health Surveillance Center (AFHSC). The AFHSC regularly compiles data on ambulatory (outpatient) encounters occurring within military treatment facilities, as well as those occurring outside these facilities (civilian care) and paid for by the US Department of Defense. A list of recruits from the units being evaluated and the dates of their complete training cycles were provided to the AFHSC. The AFHSC returned visit dates and International Classification of Diseases, Revision 9, Clinical Modification (ICD-9) codes for all outpatient medical visits during the training cycle timeframe. Five injury indices were calculated from the data provided by the AFHSC. These indices were the Installation Injury Index (III), the Modified Installation Injury Index (MIII), the Training Related Injury Index (TRII), the Comprehensive Injury Index (CII), and the Overuse Injury Index (OII). These indices included specific ICD-9 codes, as described previously [9]. The III and TRII were developed by personnel at the AFHSC. The III has been used to compare overall injury rates (acute and overuse) among military posts and is reported on a monthly basis at the AFHSC website (http://afhsc.army. mil). The TRII is limited to lower extremity overuse injuries and has been used to compare injury rates among Army basic training locations. The MIII, CII, and OII were developed by personnel in the Injury Prevention Program at the AIPH. The MIII captures a greater number of injuries than the III, including more overuse-type injuries. The CII captures all ICD-9 codes related to injuries defined as physical damage to the body as a result of an energy exchange $[10,11]$. The OII captures the subset of musculoskeletal injuries presumably resulting from cumulative microtrauma (overuse injuries) such as stress fractures, stress reactions, tendonitis, bursitis, fasciitis, arthralgia, neuropathy, radiculopathy, shin splints, synovitis, sprains, strains, and musculoskeletal pain (not otherwise specified).

Recruits that attrited from training, as well as the date and reason, were provided by the training companies. These data were verified from information in the Directorate of Human Resources, Trainee Student Processing Branch at Fort Leonard Wood. Attrition could have been due to discharge from service or recycling. A discharge was a recruit who was not suitable for service in the Army and was formally released from their service commitment. A discharge could have been due to a medical condition that existed prior to service or developed during $\mathrm{BCT}$, or for a non-medical reason. Non-medical discharges were generally due to the inability of the recruit to adapt to the military environment because of lack of ability (could not adequately perform critical military tasks) or for psychosocial reasons (lack of motivation, inability to follow orders, personality problems, commission of serious offenses). A recycle was a recruit who needed additional training to complete training requirements and was sent to another unit to complete this training. Recycles were not followed once they left their initial training unit.

\section{Data analysis}

Age was calculated from the date of birth to the date of the start of training. Body mass index (BMI) was calculated as weight $/$ height $^{2}$ obtained from the questionnaire [12]. Cumulative injury incidence was calculated as the number of recruits with $\geq 1$ injury/the total number of recruits $\times 100 \%$. Injury incidence rate was calculated as the number of recruits with $\geq 1$ injury/the total number 
of recruits $\times$ number of days in training (injuries/1,000 person-days).

Other analyses were performed using the Statistical Package for the Social Sciences (SPSS), Version 18.0. Cox regression (survival analysis) was used to examine the association between the time to the first CII injury and potential injury risk factors. Once a recruit had an injury, his contribution to time in training was terminated (censored). Those who attrited from training had their time censored at the day they left training, unless their time had already been censored as the result of an injury. All potential risk factors were entered into the regression models as categorical variables. Continuous variables were converted to categorical variables based on recommendations from the literature or findings from previous basic training investigations [5,13,14]. Age was separated into 4 groups $(<20.0,20.0-24.9$, $25.0-29.9$, and $\geq 30.0$ years). BMI was separated into 4 groups $\left(<18.5,18.5-24.9,25.0-29.9\right.$ and $\left.\geq 30.0 \mathrm{~kg} / \mathrm{m}^{2}\right)$ as recommended by the National Institute of Health [15]. Physical activity questions were categorized based on American College of Sports Medicine recommended frequency of physical activity [16]. For all Cox regressions, simple contrasts were used, comparing the injury hazard at a baseline stratum of a variable (defined with a hazard ratio (HR) of 1.00) with other strata of the same variable. Variables were included in a multivariate backward stepping Cox regression if they achieved $\mathrm{p}<0.10$ in the univariate analyses [17]. Multivariate Cox regressions established the association between a variable and injury risk while controlling for other significant injury risk factors.

\section{Results}

The mean \pm standard deviation age, height, weight, and BMI of the recruits was $21.6 \pm 3.9$ years, $177 \pm 7 \mathrm{~cm}$, $78 \pm 12 \mathrm{~kg}$, and $24.9 \pm 3.4 \mathrm{~kg} / \mathrm{m}^{2}$, respectively. Most recruits graduated $(91.5 \%, \mathrm{n}=1,494)$ but $3.0 \%(\mathrm{n}=49)$ received medical discharges, $3.6 \%(n=58)$ received other than medical discharges, $1.9 \%(\mathrm{n}=31)$ were recycled, and $0.1 \%(\mathrm{n}=1)$ went absent without leave.

Table 1 shows the injury incidence and injury incidence rates for each of the injury indices. The entire cohort contributed a total of 153,250 person-days of risk.

Table 2 displays the univariate associations between injury risk and the variables under investigation. Not all recruits answered all questions so the sample sizes are shown. Higher injury risk was associated with older age, higher and lower BMI, having smoked $\geq 100$ cigarettes in the past, smoking $\geq 20$ cigarettes in the 30 days before ENG training, a lower level of physical activity compared to peers, less frequent exercise/sports, less frequent running/jogging, less frequent weight training, a shorter history of running/jogging or weight training, a prior lower
Table 1 Injury incidences and injury incidence rates in combat engineer training

\begin{tabular}{lcc}
\hline Injury index & $\begin{array}{c}\text { Injury } \\
\text { incidence (\%) }\end{array}$ & $\begin{array}{c}\text { Injury incidence rate } \\
\text { (injuries/1,000 person-days) }\end{array}$ \\
\hline Installation injury index & 44.2 & 4.64 \\
$\begin{array}{l}\text { Modified installation } \\
\text { injury index }\end{array}$ & 46.5 & 4.88 \\
$\begin{array}{l}\text { Overuse injury index } \\
\text { Training-related injury }\end{array}$ & 38.1 & 4.00 \\
index & 31.1 & 3.27 \\
$\begin{array}{l}\text { Comprehensive injury } \\
\text { index }\end{array}$ & 46.7 & 4.91 \\
\hline
\end{tabular}

limb injury (especially if that injury prevented activity for $\geq 1$ week or the recruit had not totally recovered from the injury) and a lower level of educational attainment.

Table 3 shows the results of the multivariate Cox regression. Multivariate Cox regression requires complete data on all variables and this was available on 1,620 recruits (99\%). Independent injury risk factors included older age, lower BMI, a lower physical activity self-rating, reporting not having recovered from a previous injury and a lower level of educational attainment.

\section{Discussion}

The present investigation was the first to quantify the injury risk and identify injury risk factors in ENG training, and one of the few [6,7] to explore these issues in any type of OSUT training. Past investigations of infantry [6] and MP OSUT [7] that used a definition of injury similar or identical to that of the present investigation [7] found injury incidences of $46 \%$ and $34 \%$, respectively. This compares with the incidence of $47 \%$ in the present study. The high injury incidence in combat engineer and infantry training likely reflect the intensity and variety of physical activities in these occupational specialties that put the recruits at risk of injury. Previous studies in basic training $[18,19]$ and studies in the civilian sector $[20,21]$ have shown that as physical activity increases so does the incidence of injuries.

In addition to documenting injury incidence, the present investigation identified a number of factors that put recruits at higher injury risk. Older age was an independent injury risk factor among both men and women and this is in consonance with other studies in BCT [2,5,6,22,23] and MP OSUT [7], as well as other military and civilian investigations where participants performed similar levels of physical activity [24-26]. Of interest was the fact that during the time of this study the age requirement for entry into the Army had been liberalized to allow into service individuals 17 to 45 years of age, whereas previously it had been 17 to 35 years. The present investigation had 31 individuals over the age of 
Table 2 Univariate associations between variables and injury risk among combat engineer recruits

\begin{tabular}{|c|c|c|c|c|c|c|}
\hline Variable group & Variable & Strata & $\mathrm{N}$ & $\begin{array}{l}\text { Injury incidence } \\
\text { (\%) }\end{array}$ & $\begin{array}{l}\text { Hazard ratio } \\
(95 \% \mathrm{Cl})\end{array}$ & $\begin{array}{c}\text { p-value } \\
\text { (Wald statistic) }\end{array}$ \\
\hline \multirow[t]{4}{*}{ Age } & \multirow[t]{4}{*}{ Age } & $<20.0$ years & 722 & 44.3 & 1.00 & Referent \\
\hline & & 20.0-24.9 years & 690 & 46.7 & $1.12(0.96-1.31)$ & 0.14 \\
\hline & & 25.0-29.9 years & 144 & 50.7 & $1.30(1.01-1.68)$ & 0.04 \\
\hline & & $\geq 30.0$ years & 77 & 62.3 & $1.81(1.34-2.46)$ & $<0.01$ \\
\hline \multirow[t]{4}{*}{ BMI } & \multirow[t]{4}{*}{ BMl } & $<18.5 \mathrm{~kg} / \mathrm{m}^{2}$ & 27 & 74.1 & $2.32(1.48-3.64)$ & $<0.01$ \\
\hline & & $18.5-24.9 \mathrm{~kg} / \mathrm{m}^{2}$ & 845 & 46.9 & 1.00 & Referent \\
\hline & & $25.0-29.9 \mathrm{~kg} / \mathrm{m}^{2}$ & 628 & 43.5 & $0.93(0.80-1.09)$ & 0.37 \\
\hline & & $\geq 30 \mathrm{~kg} / \mathrm{m}^{2}$ & 127 & 54.3 & $1.38(1.07-1.78)$ & 0.02 \\
\hline \multirow[t]{22}{*}{ Prior tobacco use } & \multirow[t]{2}{*}{ Smoked $\geq 100$ cigarettes in life } & No & 1000 & 44.8 & 1.00 & Referent \\
\hline & & Yes & 632 & 49.8 & $1.17(1.01-1.35)$ & 0.04 \\
\hline & \multirow[t]{4}{*}{ Age started smoking } & Never smoked & 745 & 46.7 & 1.00 & Referent \\
\hline & & $<13$ years & 84 & 50.0 & $1.08(0.79-1.49)$ & 0.63 \\
\hline & & $13-16$ years & 550 & 47.5 & $1.02(0.87-1.20)$ & 0.81 \\
\hline & & $\geq 17$ years & 254 & 44.2 & $0.92(0.75-1.14)$ & 0.47 \\
\hline & \multirow{4}{*}{$\begin{array}{l}\text { Days smoked in } 30 \text { days before } \\
\text { ENG training }\end{array}$} & None & 1098 & 46.0 & 1.00 & Referent \\
\hline & & 1-9 days & 146 & 45.9 & $1.00(0.77-1.29)$ & 0.99 \\
\hline & & 10-19 days & 92 & 46.7 & $1.00(0.74-1.37)$ & 0.98 \\
\hline & & $\geq 20$ days & 297 & 49.8 & $1.11(0.92-1.33)$ & 0.27 \\
\hline & \multirow{4}{*}{$\begin{array}{l}\text { Cigarettes smoked in } 30 \text { days } \\
\text { before ENG training }\end{array}$} & None & 1112 & 46.2 & 1.00 & referent \\
\hline & & 1-9 cigarettes/day & 303 & 47.2 & $1.00(0.83-1.21)$ & 0.98 \\
\hline & & 10-19 cigarettes/day & 146 & 45.2 & $0.98(0.76-1.26)$ & 0.86 \\
\hline & & $\geq 20$ cigarettes/day & 71 & 54.9 & $1.36(0.98-1.88)$ & 0.07 \\
\hline & \multirow{4}{*}{$\begin{array}{l}\text { Days of smokeless tobacco use } \\
\text { in } 30 \text { days before ENG training }\end{array}$} & None & 1331 & 48.5 & 1.00 & Referent \\
\hline & & 1-9 days & 72 & 37.5 & $0.73(0.50-1.07)$ & 0.11 \\
\hline & & 10-19 days & 61 & 38.4 & $0.74(0.41-1.05)$ & 0.14 \\
\hline & & $\geq 20$ days & 168 & 48.7 & $1.01(0.61-1.32)$ & 0.12 \\
\hline & \multirow{4}{*}{$\begin{array}{l}\text { Amount of smokeless tobacco } \\
\text { use in } 30 \text { days before ENG } \\
\text { training }\end{array}$} & None & 1341 & 48.2 & 1.00 & Referent \\
\hline & & $\leq 3 / 4$ cans, plugs & 125 & 41.2 & $0.84(0.67-1.05)$ & 0.14 \\
\hline & & 1 to $1-3 / 4$ cans, plugs & 121 & 41.7 & $0.84(0.69-1.09)$ & 0.11 \\
\hline & & $\geq 2$ cans, plugs & 43 & 51.2 & $1.16(0.76-1.77)$ & 0.50 \\
\hline \multirow[t]{13}{*}{ Prior physical activity } & \multirow{5}{*}{$\begin{array}{l}\text { Physical activity before ENG } \\
\text { training, compared to other of } \\
\text { same age and sex }\end{array}$} & Much less active & 70 & 67.1 & $2.46(1.75-3.47)$ & $<0.01$ \\
\hline & & Less active & 293 & 59.7 & $1.83(1.44-2.33)$ & $<0.01$ \\
\hline & & Average & 421 & 42.8 & $1.12(0.88-1.42)$ & 0.38 \\
\hline & & More active & 583 & 43.7 & $1.13(0.90-1.42)$ & 0.29 \\
\hline & & Much more active & $x 265$ & 40.0 & 1.00 & Referent \\
\hline & \multirow{3}{*}{$\begin{array}{l}\text { Exercise or sports frequency } \\
2 \text { months before ENG training }\end{array}$} & $\leq 1$ time/week & 187 & 58.3 & $1.76(1.40-2.22)$ & $<0.01$ \\
\hline & & 2-4 time/week & 907 & 48.2 & $1.26(1.07-1.49)$ & $<0.01$ \\
\hline & & $\geq 5$ time/week & 538 & 40.3 & 1.00 & Referent \\
\hline & \multirow{3}{*}{$\begin{array}{l}\text { Running/jogging Frequency } \\
\text { before ENG training }\end{array}$} & $\leq 1$ time/week & 478 & 52.3 & $1.46(1.15-1.86)$ & $<0.01$ \\
\hline & & 2-4 times/week & 926 & 45.6 & $1.17(0.93-1.47)$ & 0.17 \\
\hline & & 5-7 times/week & 227 & 39.6 & 1.00 & Referent \\
\hline & \multirow{2}{*}{$\begin{array}{l}\text { Time running/jogging before } \\
\text { ENG training }\end{array}$} & $\leq 1$ month & 484 & 50.4 & $1.38(1.10-1.72)$ & $<0.01$ \\
\hline & & 2-6 months & 876 & 46.6 & $1.19(0.97-1.47)$ & 0.11 \\
\hline
\end{tabular}


Table 2 Univariate associations between variables and injury risk among combat engineer recruits (Continued)

\begin{tabular}{|c|c|c|c|c|c|c|}
\hline & & $\geq 7$ months & 273 & 40.7 & 1.00 & Referent \\
\hline & \multirow{3}{*}{$\begin{array}{l}\text { Weight training frequency before } \\
\text { ENG training }\end{array}$} & $\leq 1$ time/week & 646 & 51.5 & $1.28(1.04-1.57)$ & 0.02 \\
\hline & & 2-4 times/week & 699 & 43.8 & $0.99(0.81-1.22)$ & 0.95 \\
\hline & & 5-7 times/week & 286 & 43.4 & 1.00 & Referent \\
\hline & \multirow{3}{*}{$\begin{array}{l}\text { Time weight training before ENG } \\
\text { training }\end{array}$} & $\leq 1$ month & 671 & 50.7 & $1.30(1.08-1.56)$ & $<0.01$ \\
\hline & & 2-6 months & 544 & 45.2 & $1.12(0.92-1.36)$ & 0.26 \\
\hline & & $\geq 7$ months & 417 & 42.2 & 1.00 & Referent \\
\hline \multirow[t]{8}{*}{ Prior injury } & \multirow[t]{2}{*}{ Prior lower limb injury } & No & 1234 & 45.3 & 1.00 & Referent \\
\hline & & Yes & 399 & 51.1 & $1.21(1.03-1.43)$ & 0.02 \\
\hline & \multirow{3}{*}{$\begin{array}{l}\text { Prior injury prevent activities } \\
\geq 1 \text { week }\end{array}$} & No prior injury & 1234 & 45.3 & 1.00 & Referent \\
\hline & & No & 131 & 47.3 & $1.04(0.80-1.36)$ & 0.76 \\
\hline & & Yes & 267 & 52.8 & $1.30(1.08-1.57)$ & $<0.01$ \\
\hline & \multirow{3}{*}{$\begin{array}{l}\text { Totally recovered from prior } \\
\text { injury }\end{array}$} & No prior injury & 1229 & 45.2 & 1.00 & Referent \\
\hline & & No & 18 & 61.1 & $2.17(1.19-3.93)$ & 0.01 \\
\hline & & Yes & 380 & 50.5 & $1.18(1.00-1.39)$ & 0.05 \\
\hline \multirow[t]{16}{*}{ Demo-graphics } & \multirow[t]{3}{*}{ Component } & Active Army & 972 & 47.8 & 1.00 & Referent \\
\hline & & National Guard & 463 & 45.1 & $0.89(0.76-1.05)$ & 0.17 \\
\hline & & Army Reserve & 198 & 44.9 & $0.96(0.76-1.20)$ & 0.69 \\
\hline & \multirow[t]{5}{*}{ Educational level } & $<$ High school graduate & 99 & 57.6 & $1.39(1.05-1.82)$ & 0.02 \\
\hline & & High school graduate & 1315 & 46.3 & 1.00 & Referent \\
\hline & & Some college & 150 & 46.0 & $1.01(0.79-1.30)$ & 0.93 \\
\hline & & $\geq$ College graduate & 52 & 40.4 & $0.91(0.59-1.40)$ & 0.66 \\
\hline & & Unknown & 17 & 41.2 & $0.83(0.40-1.75)$ & 0.63 \\
\hline & \multirow[t]{5}{*}{ Race/ethnicity } & White & 1122 & 45.5 & 1.00 & Referent \\
\hline & & Black & 239 & 49.0 & $1.09(0.89-1.34)$ & 0.39 \\
\hline & & Hispanic & 191 & 49.2 & $1.08(0.87-1.34)$ & 0.50 \\
\hline & & Other & 78 & 53.8 & $1.32(0.96-1.81)$ & 0.09 \\
\hline & & Missing & 3 & 0.0 & a & a \\
\hline & \multirow[t]{3}{*}{ Marital status } & Single, never married & 1380 & 50.0 & 1.00 & Referent \\
\hline & & Married & 238 & 46.1 & $1.16(0.96-1.42)$ & 0.13 \\
\hline & & Other & 15 & 53.3 & $1.16(0.58-2.33)$ & 0.68 \\
\hline
\end{tabular}

${ }^{a}$ Not included in the analysis.

35 and this made up only $1.9 \%$ of the entire cohort, but $40 \%$ of those over the age of 30 years.

The reason for the higher susceptibility to injury in older recruits may have to do with age-related changes in stem cells that slow tissue healing [27-29], age-related declines in fitness [30,31] since lower fitness has been shown to be associated with injuries [1,2,22,32-35] and/ or prior injury history since older recruits may be more likely to have experienced lower limb injuries in the past that make them more susceptible to injuries during ENG training [33,36-39]. To examine if older recruits were more likely to report a prior injury in the present investigation, self-reported prior lower limb injuries were stratified by age. Table 4 shows that younger and older age groups generally had similar differences in injury incidence so the hypothesis was not supported here. This is similar to findings in other investigations $[7,26]$.

Beside older age, the present study found that recruits with either high or low levels of BMI had higher injury risk compared to those of "normal" BMI, although in the multivariate analysis the risk at the highest BMI level ("obese") was reduced compared to the univariate result. Most basic training studies have reported bimodal relationships $[1,22,35,40]$, although a few $[2,41]$ have not, or have reported increased risk with only high [42] or low [43] BMI. The latter two studies [42,43] had a very narrow range of BMIs perhaps making it difficult to demonstrate a bimodal relationship. High BMI generally indicates a larger percentage of body fat $[12,44]$, although it is also possible to have a high BMI as a result 
Table 3 Multivariate association between variables and injury risk among combat engineer recruits

\begin{tabular}{|c|c|c|c|c|}
\hline Variable & Strata & $\mathrm{N}$ & Hazard ratio $(95 \% \mathrm{Cl})$ & p-value \\
\hline \multirow[t]{4}{*}{ Age } & $<20.0$ years & 716 & 1.00 & Referent \\
\hline & 20.0-24.9 years & 684 & $1.16(0.98-1.36)$ & 0.08 \\
\hline & 25.0-29.9 years & 143 & $1.48(1.13-1.94)$ & $<0.01$ \\
\hline & $\geq 30.0$ years & 77 & $2.36(1.69-3.28)$ & $<0.01$ \\
\hline \multirow[t]{4}{*}{ BMI } & $<18.5 \mathrm{~kg} / \mathrm{m} 2$ & 27 & $2.39(1.52-3.75)$ & $<0.01$ \\
\hline & $18.5-24.9 \mathrm{~kg} / \mathrm{m}^{2}$ & 844 & 1.00 & Referent \\
\hline & $25.0-29.9 \mathrm{~kg} / \mathrm{m}^{2}$ & 623 & $0.86(0.73-1.00)$ & 0.06 \\
\hline & $\geq 30 \mathrm{~kg} / \mathrm{m}^{2}$ & 126 & $1.16(0.90-1.51)$ & 0.26 \\
\hline \multirow{5}{*}{$\begin{array}{l}\text { Physical activity before basic training } \\
\text { compared to peers }\end{array}$} & Much less active & 70 & $2.46(1.73-3.49)$ & $<0.01$ \\
\hline & Less active & 289 & $1.85(1.45-2.37)$ & $<0.01$ \\
\hline & Average & 418 & $1.15(0.90-1.47)$ & 0.28 \\
\hline & More active & 579 & $1.13(0.90-1.42)$ & 0.30 \\
\hline & Much more active & 264 & 1.00 & Referent \\
\hline \multirow[t]{3}{*}{ Totally recovered from prior injury } & No prior injury & 1226 & 1.00 & Referent \\
\hline & No & 18 & $2.21(1.20-4.08)$ & 0.01 \\
\hline & Yes & 376 & $1.15(0.98-1.36)$ & 0.09 \\
\hline \multirow[t]{5}{*}{ Educational level } & $<$ High school graduate & 98 & $1.43(1.09-1.89)$ & 0.01 \\
\hline & High school graduate & 1305 & 1.00 & Referent \\
\hline & Some college & 149 & $0.94(0.73-1.22)$ & 0.66 \\
\hline & $\geq$ College graduate & 51 & $0.62(0.39-1.00)$ & 0.05 \\
\hline & Unknown & 17 & $0.86(0.41-1.82)$ & 0.70 \\
\hline
\end{tabular}

of a higher amount of fat-free mass [45]. Low BMI may reflect a paucity of either fat, fat-free mass, or both. Low BMI may make recruits more susceptible to injury if they lack the muscle mass or strength in the supportive structures (ligaments, bones) required to perform certain physical tasks and/or if they overexert or overuse the available muscle mass or supportive structures leading to injuries. On the other hand, injury risk might be increased among those with high BMI because the additional mass would increase the intensity of physical activity [46] leading to more rapid fatigue and impose a higher volume of repetitive stress on the musculoskeletal system because of the greater weight relative to height.
Compared to $\mathrm{BCT}$ or MP training $[1,7,40]$, these factors may especially exacerbate injuries in ENG training because of the types of physical activities that ENGs perform, especially in activities involving construction of fighting positions and erection of obstacles.

In the present investigation, recruits who reported smoking $\geq 100$ cigarettes in the past were at higher injury risk and there was also a trend such that those who had smoked $\geq 20$ cigarettes per day were at increased injury risk. Cigarette smoking was not an independent injury risk factor in the multivariate analysis. Nonetheless, cigarette smoking prior to basic training has consistently been associated with increased injury risk in US Army and Air

Table 4 Injuries in combat engineer training stratified by prior lower limb injury and age

\begin{tabular}{|c|c|c|c|c|c|}
\hline & Response category & $\mathbf{N}$ & Injured in ENG training (\%) & Risk ratio -prior/no prior injury $(95 \% \mathrm{Cl})$ & p-value ${ }^{a}$ \\
\hline \multirow[t]{2}{*}{$<20.0$ year olds } & No prior injury & 552 & 42.9 & $1.14(0.95-1.36)$ & 0.18 \\
\hline & Prior injury & 170 & 48.8 & & \\
\hline \multirow[t]{2}{*}{ 20.0-24.9 year olds } & No prior injury & 522 & 45.0 & $1.15(0.97-1.37)$ & 0.13 \\
\hline & Prior injury & 168 & 51.8 & & \\
\hline \multirow[t]{2}{*}{ 25.0-29.9 year olds } & No prior injury & 107 & 51.4 & $0.95(0.65-1.38)$ & 0.77 \\
\hline & Prior injury & 37 & 48.6 & & \\
\hline \multirow[t]{2}{*}{$\geq 30$ year olds } & No prior injury & 53 & 60.4 & $1.10(0.77-1.58)$ & 0.60 \\
\hline & Prior injury & 24 & 66.7 & & \\
\hline
\end{tabular}

${ }^{\text {aChi-square statistic. }}$ 
Force basic training $[2,6,34,40,47]$, MP OSUT training [7], and in the basic training of other countries [22,48]. Further, smoking was associated with injury in infantry soldiers [49] and in other occupational groups [50-52]. The association between smoking and injuries has biological plausibility, both from a physiological and psychosocial perspective. There is considerable literature showing that cigarette smoking impairs wound $[53,54]$ and bone [55-57] healing, reduces tissue strength $[58,59]$, and affects immune function. The immune system is important for tissue healing, since macrophages, leukocytes, and lymphocytes regulate various steps in the process and remove or assist in removal of damaged tissue [60-63], such as might be produced by repetitive microtrauma. Besides physiological mechanisms, psychosocial factors may also be a consideration. Prior studies show that Air Force recruits [64] and civilians [65-67] who were cigarette smokers had higher scores than nonsmokers on various measures of risk taking. It is possible that the higher risk-taking behavior of smokers manifests itself in the activities of basic training and results in a higher injury rate among smokers.

In basic training, all recruits are required to cease smoking at the beginning of training and any mechanism proposing to account for the association between smoking and injuries must take this into account. Evidence for the longer-term effects of smoking comes from studies on collagen metabolism and other studies on immune function. One study [68] found derangements in collagen metabolism among smokers. Investigators followed weekly urinary hydoxyproline/creatine levels (a marker of collagen metabolism) from individuals 14 weeks after they had ceased smoking. It was estimated (by mathematical modeling) that hydoxyproline/creatine levels would return to the level of nonsmokers in about 71 weeks, among those who had previously smoked $\leq 40$ cigarettes/day, while it would take 120 weeks to reach the same level in those who had been smoking $>40$ cigarettes/day. Immune studies suggest that smoking-induced leukocytosis slowly decreases over time once smoking ceases [69-75]. One day to 6 weeks after smoking cessation, the leukocyte count was still elevated $[71,75]$. Three months after smoking cessation, the neutrophil concentration tended to decrease [70]. Leukocyte counts approached the level of nonsmokers the longer it had been since the individual stopped smoking, but men who had quit smoking for 10 years or more still had higher leukocyte counts than nonsmokers in one study [72]. Another investigation showed that men and women who had quit smoking for an average of 11 years had counts similar to those who had never smoked [69].

There were 6 physical activity items on the questionnaire. These were designed to provide 1) a single global assessment of physical activity (self-rating compared to peers) 2) three questions on the frequency of recent (last 2 months before OSUT) physical activity (one general question, one specific to aerobic training and one specific to weight training), and 3) two questions on the history of aerobic or strength training. Results from all six questions generally indicated that a lower frequency or shorter history of physical activity was associated with higher injury risk in a generally dose-dependent manner. These data are in consonance with previous studies of military basic training that found increased risk of injury among those who self-reported less physical activity $[1,2,6,14,76,77]$. In ENG training, recruits perform weightbearing physical activity primarily in the form of standing in formation, walking, and running. It seems reasonable that a higher frequency of weight-bearing physical training prior to training would result in less susceptibility to injury because of the favorable influences of physical activity on the body. Physical activity of the proper intensity, frequency, and duration can increase aerobic fitness, muscle strength, connective tissue, bone strength, general health, and can reduce body fat [16,78-84]. These and other factors may explain the reduced susceptibility to injury among recruits who were physically active prior to ENG training [85].

Recruits who reported a prior lower limb injury were at higher injury risk. This relationship appeared to be graded, depending on the reported severity of the previous injury. That is, recruits reporting at least a weeklong limitation of the previous injury were at higher risk in training than those who had previous injury but did not report a week-long limitation; those who reported that they had not totally recovered from the previous injury where at much higher risk than those with a prior injury who had recovered. Other studies of basic training have not demonstrated a consistent relationship between prior injuries and injuries in training $[5-7,14,86]$, although this relationship has often been demonstrated in athletes [39,41,87-92]. Some authors have speculated that contractile or connective scar tissues may alter movement mechanics, or that muscle tissue atrophy induced by some injuries might reduce strength or result in muscle imbalances that could affect injuries [93,94]. Many injuries may be chronic or recurrent, accounting for at least a part of this relationship.

A lower level of education was an injury risk factor in both the univariate and multivariate analyses and a dose-response relationship was evident such that risk increased from high to low education. In consonance with the finding here, other investigations have found a graded relationship between injury-related morbibidity/ mortality and educational attainment and/or various measures of intelligence in both military $[95,96]$ and civilian $[97,98]$ studies. Greater educational attainment may be associated with behaviors conducive to injury 
prevention [99] and/or the ability to more rapidly and effectively process information relating to risk reduction.

One of the limitations to the present study was the lack of prospective measures of physical fitness. Physical fitness has consistently been shown to be an independent risk factor for injuries in past investigations $[1,2,5,13]$. The Army Physical Fitness Test (APFT) was administered to recruits but it was given two to three weeks after the start of training. Since several physical training sessions were likely to have occurred since the start of training, and since recruits were likely to have considerably increased their physical fitness in this time, the first APFT could not serve as a baseline level of fitness.

\section{Conclusions}

This paper has identified a number of key risk factors that can be used to target and suggest future prevention strategies for this and similar young, healthy populations. The multivariate model identified several important risk factors for injuries in this population including older age, lower body mass index, low prior physical activity levels, inadequate recovery from past injuries, and lower educational level. While older age per se as a risk factor cannot be modified, the degree of risk may be modifiable by starting training at lower levels and increasing training it more slowly as recommended for other at risk populations [100,101]. In regard to BMI, the Army has traditionally focused on screening for underweight soldiers and the focus on overweight has only been in place since 1960 [102]. The data presented in this paper suggest that consideration be given to underweight recruits, perhaps in terms of screening and/ or increasing muscle mass and fitness levels. The excess risk of injury for recruits who reported low levels of physical activity prior to entering the Army is consistent with past studies and might be mitigated by initiating training at lower intensities and amounts followed by a more gradual progression of training as previously suggested [85,101]. Regarding injuries, it is not surprising that inadequate recovery from past injuries is a risk factor for future injuries. In the absence of stronger evidence, common sense dictates that soldiers who have sustained injuries should be given adequate time to recover and training should be structured to reduce pain and physiologic strain on the injured part [101]. The Army should continue its focus on recruiting those with higher educational level. In summary, findings from this study clearly show that modifiable risk factors can be identified by systematic research and used to recommend prevention strategies for injuries resulting from vigorous physical training activities, such as Army ENG training.

\section{Abbreviations}

US: United States; ENG: Engineer; MP: Military police; BCT: Basic combat training; OSUT: One station unit training; DMDC: Defense manpower data center; DMSS: Defense medical surveillance system; AFHSC: Armed forces health surveillance center; ICD-9: International classification of diseases, revision 9, clinical modification; III: Installation injury index; MIII: Modified installation injury index; TRII: Training related injury index; CII: Comprehensive injury index; Oll: Overuse injury index; BMI: Body mass index; HR: Hazard ratio; 95\% Cl: 95\% confidence interval; APFT: Army physical fitness test.

\section{Competing interests}

The authors have no competing interests.

\section{Authors' contributions}

JJK participated in the design of the study, assisted with data collection, assisted with compiling the data, performed the statistical analysis, interpreted the data, and drafted the manuscript. BG, JC, DT, RS collected and complied data, assisted with the interpretation of the data, and helped draft the manuscript. BHJ participated in the design of the study, assisted in the interpretation of the data, and helped draft the manuscript. All authors read and approved the final manuscript.

\section{Authors' information}

The views, opinions, and/or findings contained in this report are those of the authors and should not be construed as official Department of the Army position, policy, or decision, unless so designated by other official documentation. Approved for public release; distribution is unlimited.

\section{Acknowledgements}

We would like to thank individuals who assisted with the organization of this investigation including Ms Martha Collins, LTC Dean Kucera, MSG James Clayton, LTC Glasscock, MSG Kirk Lamb, SGM William Lindsey, Ms Portia Ellis and Mr Brian Raymond. This research was supported in part by an appointment to the Knowledge Preservation Program at the U.S. Army Public Health Command (USAPHC) administered by the Oak Ridge Institute for Science and Education through an interagency agreement between the U.S. Department of Energy and USAPHC.

\section{Author details}

${ }^{1}$ US Army Institute of Public Health, Epidemiology and Disease Surveillance Portfolio, ATTN: MCHB-IP-DI, 5158 Blackhawk Rd, Aberdeen Proving Ground, MD 21010, USA. ${ }^{2}$ Hawaii Department of Health, Honolulu, HI, USA. ${ }^{3}$ Department of Obstetrics and Gynecology, Medical University of South Carolina, Charleston, SC, USA. ${ }^{4}$ AIDS Resource Center of Wisconsin, Milwaukee, WI, USA.

Received: 24 December 2012 Accepted: 22 February 2013

Published: 5 March 2013

\section{References}

1. Jones BH, Bovee MW, Harris JM, Cowan DN: Intrinsic risk factors for exercise-related injuries among male and female Army trainees. Am J Sports Med 1993, 21:705-710.

2. Knapik JJ, Sharp MA, Canham-Chervak M, Hauret K, Patton JF, Jones BH: Risk factors for training-related injuries among men and women in Basic Combat Training. Med Sci Sports Exerc 2001, 33:946-954.

3. Bell NS, Mangione TW, Hemenway D, Amoroso PJ, Jones BH: High injury rates among female army trainees. A function of gender? Am J Prev Med 2000, 18(Suppl. 3):141-146.

4. Kowal DM, Patton JF, Vogel JA: Psychological states and aerobic fitness of male and female recruits before and after basic training. Aviat Space Environ Med 1978, 49:603-606.

5. Knapik JJ, Swedler D, Grier T, Hauret KG, Bullock S, Williams K, Darakjy S, Lester $\mathrm{M}$, Tobler $\mathrm{S}$, Jones BH: Injury reduction effectiveness of selecting running shoes based on plantar shape. J Strength Cond Res 2009, 23:685-697.

6. Jones BH, Cowan DN, Tomlinson JP, Robinson JR, Polly DW, Frykman PN: Epidemiology of injuries associated with physical training among young men in the Army. Med Sci Sports Exerc 1993, 25:197-203.

7. Knapik JJ, Graham B, Cobbs J, Thompson D, Steelman R, Jones BH: A prospective investigation of injury incidence and injury risk factors 
among Army recruits in military police training. BMC Musculoskel Disord 2013, 14(1):32. Epub ahead of print.

8. Hodge JG: An enhanced approach to distinguishing public health practice and human subjects research. J Law Med Ethics 2005, 33:125-141.

9. Knapik JJ, Darakjy S, Scott S, Hauret KG, Canada S, Marin R, Palkoska F, VanCamp S, Piskator E, Rieger W, et al: Evaluation of two Army fitness programs: the TRADOC Standardized Physical Training Program for Basic Combat Training and the Fitness Assessment Program. Aberdeen Proving Ground, MD: US Army Center for Health Promotion and Preventive Medicine, Technical Report No. 12-HF-5772B-04; 2004

10. Haddon W: Energy damage and ten countermeasure strategies. J Trauma 1973, 13:321-331.

11. Haddon W: Advances in the epidemiology of injury as a basis for public policy. Public Health Rep 1980, 95:411-421.

12. Knapik JJ, Burse RL, Vogel JA: Height, weight, percent body fat and indices of adiposity for young men and women entering the U.S. Army. Aviat Space Environ Med 1983, 54:223-231.

13. Knapik JJ, Brosch LC, Venuto M, Swedler DI, Bullock SH, Gaines LS, Murphy RJ, Tchandja J, Jones BH: Effect on injuries of assigning shoes based on foot shape in Air Force Basic Training. Am J Prev Med 2010, 38:S197-S211.

14. Knapik JJ, Trone D, Swedler DI, Villasenor A, Schmied E, Bullock S, Jones BH: Injury reduction effectiveness of assigning running shoes based on foot shape in Marine Corps basic training. Aberdeen Proving Ground MD: US Army Center for Health Promotion and Preventive Medicine, No. 12-MA-05SBA-08B; 2009.

15. National Institute of Health $(\mathrm{NIH})$ : Clinical guidelines on the identification, evaluation, and treatment of overweight and obesity in adult. Bethesda MD: National Institutes of Health NIH Publication No. 98-4083; 1998.

16. American College of Sports Medicine: The recommended quantity and quality of exercise for developing and maintaining cardiorespiratory and muscular fitness, and flexibility in healthy adults. Med Sci Sports Exerc 1998, 30:975-991.

17. Hosmer DW, Lemeshow S: Applied Logistic Regression. New York: John Wiley \& Sons; 1989.

18. Knapik JJ, Hauret KG, Canada S, Marin R, Jones BH: Association between ambulatory physical activity and injuries in United States Army Basic Training. J Phys Act Health 2011, 8(4):496-502.

19. Almeida SA, Williams KM, Shaffer RA, Brodine SK: Epidemiological patterns of musculoskeletal injuries and physical training. Med Sci Sports Exerc 1999, 31:1176-1182

20. Lubetzky-Vilnai A, Carmeli E, Katz-Leurer M: Prevalence of injuries among young adults in sports centers: relation to the type and pattern of activity. Scand J Med Sci Sports 2008, 19:828-833.

21. Pollock ML, Gettman LR, Milesis CA, Bah MD, Durstine L, Johnson RB: Effects of frequency and duration of training on attrition and incidence of injury. Med Sci Sports Exerc 1977, 9:31-36.

22. Heir T, Eide G: Injury proneness in infantry conscripts undergoing a physical training programme: smokeless tobacco use, higher age, and low levels of physical fitness are risk factors. Scand J Med Sci Sports 1997 7:304-311.

23. Knapik JJ, Spiess A, Swedler D, Grier T, Darakjy S, Amoroso P, Jones BH: Injury risk factors in parachuting and acceptability of the parachute ankle brace. Aviat Space Environ Med 2008, 79:689-694.

24. Craig SC, Lee T: Attention to detail: injuries at altitude among U.S. Army military static line parachutists. Mil Med 2000, 165:268-271.

25. Schmidt MD, Sulski SI, Amoroso PJ: Effectiveness of an external ankle brace in reducing parachute-related ankle injuries. Med Sci Sports Exerc 2004, 36:S312.

26. Knapik JJ, Grier T, Spiess A, Swedler DI, Hauret KG, Graham B, Yoder J, Jones $\mathrm{BH}$ : Injury rates and injury risk factors among Federal Bureau of Investigation new agent trainees. BMC Publ Health 2011, 11:920. doi:910.1186/1471-2458-1111-1920

27. Schmitt R, Cantley LG: The impact of ageing on kidney repair. Am J Physiol Renal Physiol 2008, 294:F1265-F1272.

28. Conboy IM, Rando TA: Aging, stem cells and tissue regeneration. Cell Cycle 2005, 4:407-410

29. Pittman J: Effects of aging on wound healing: current concepts. J Wound Ostomy Continence Nurs 2007, 34:412-415.

30. Barowclough F: The process of aging. J Adv Nur 1981, 6:319-325.

31. Knapik JJ, Jones BH, Vogel JA, Banderet LE, Bahrke MS, O'Connor JS: Influence of age and body mass index on measures of physical fitness in U.S. Army Soldiers. J Aging Phys Act 1996, 4:234-250.
32. Jones BH, Bovee MW, Knapik JJ: Associations among body composition, physical fitness, and injuries in men and women Army trainees. In Body Composition and Physical Performance. Edited by Marriott BM, GrumstrupScott J. Washington, D.C: National Academy Press; 1992:141-173.

33. Rauh MJ, Macera CA, Trone DW, Shaffer RA, Brodine SK: Epidemiology of stress fracture and lower-extremity overuse injuries in female recruits. Med Sci Sports Exerc 2006, 38:1571-1577.

34. Knapik JJ, Brosch LC, Venuto M, Swedler DI, Bullock SH, Gaines LS, Murphy RJ Canada SE, Hoedebecke EL, Tobler SK, et al: Injury reduction effectiveness of prescribing running shoes based on foot shape in Air Force Basic Military Training. Aberdeen Proving Ground MD: Army Center for Health Promotion and Preventive Medicine, Technical Report No. 12-MA-05SBA-08A; 2008.

35. Heir T, Eide G: Age, body composition, aerobic fitness and health condition as risk factors for musculoskeletal injuries in conscripts. Scand J Med Sci Sports 1996, 6:222-227.

36. Forde MS, Punnett L, Wegman DH: Prevalence of musculoskeletal symptoms in union ironworkers. J Occup Env Hyg 2005, 2:203-212.

37. Knapik JJ, McCollam R, Canham-Chervak M, Arnold S, DuVernoy TS, Hoedebecke EL: A second investigation of injuries among officers attending the US Army War College during Academic Year 2000. Aberdeen Proving Ground, MD: US Army Center for Health Promotion and Preventive Medicine, EPICON Report No. 29-HE-2682-00; 2000.

38. Knapik JJ, Spiess A, Darakjy S, Grier T, Manning F, Livingstone E, Swedler D, Amoroso $\mathrm{P}$, Jones $\mathrm{BH}$ : Risk factors for parachute injuries and comments about the parachute ankle brace among airborne students. Aberdeen Proving Ground MD: US Army Center for Health Promotion and Preventive Medicine, Technical Report No. 12-MA01Q2-08B; 2008.

39. Walter SD, Hart LE, McIntosh JM, Sutton JR: The Ontario cohort study of running-related injuries. Arch Int Med 1989, 149:2561-2564.

40. Knapik JJ, Swedler D, Grier T, Hauret KG, Bullock S, Williams K, Darakjy S, Lester $\mathrm{M}$, Tobler $\mathrm{S}$, Clemmons $\mathrm{N}$, et al: Injury reduction effectiveness of prescribing running shoes based on foot shape in Basic Combat Training. Aberdeen Proving Ground MD: US Army Center for Health Promotion and Preventive Medicine, Technical Report No. 12-MA-05SB-08; 2008.

41. Rauh MJ, Koepsell TD, Rivara FP, Margherita AJ, Rice SG: Epidemiology of musculoskeletal injuries among high school cross-country runners. Am J Epidemiol 2006, 163:151-159.

42. Ross J, Woodward A: Risk factors of injury during basic military training. J Occ Med 1994, 10:1120-1126.

43. Wang $X$, Wang PS, Zhou W: Risk factors of military training-related injuries in recruits of Chinese People's Armed Police Force. Chin $J$ Traumatol 2003, 6:12-17.

44. Deurenberg P, Weststrate JA, Seidell JC: Body mass index as a measure of body fatness: age- and sex-specific prediction formulas. Brit J Nutr 1991, 65:105-114.

45. Friedl KE: Can you be large and not obese? The distinction between body weight, body fat, and abdominal fat in occupational standards. Diabetes Technol Ther 2004, 6:732-749.

46. Cureton KJ: Effects of experimental alterations in excess weight on physiological responses to exercise and physical performanc. In Body Composition and Physical Performance Applications for Military Services. Edited by Marriott BM, Grumstrup-Scott J. Washington, D.C: National Academy Press; 1992

47. Altarac M, Gardner JW, Popovich RM, Potter R, Knapik JJ, Jones BH: Cigarette smoking and exercise-related injuries among young men and women. Am J Prev Med 2000, 18(Suppl 3S):96-102.

48. Valimaki W, Alfthan E, Lehmuskallio E, Loyttyniemi E, Sah T, Suominen H, Valimakii MJ: Risk factors for clinical stress fractures in male military recruits: a prospective cohort study. Bone 2005, 37:267-273.

49. Reynolds KL, Heckel HA, Witt CE, Martin JW, Pollard JA, Knapik JJ, Jones BH: Cigarette smoking, physical fitness, and injuries in infantry soldiers. Am J Prev Med 1994, 10:145-150

50. Chau N, Bourgkard E, Bhattacherjee A, Ravaud JF, Choquet M, Mur JM: Associations of job, living conditions and lifestyle with occupational injury in working population: a population-based study. Int Arch Occup Environ Health 2008, 81:379-389.

51. McSweeney KP, Congleton JJ, Kerk CJ, Jenkins OE, Craig BN: Correlation of recorded injury and illness data with smoking, exercise, and absolute aerobic capacity. Int J Ind Ergonomics 1999, 24:193-200.

52. Craig BN, Congleton JJ, Kerk CJ, Amendola AA, Gaines WG: Personal and non-occupational risk factors and occupational injury/illness. Am J Ind Med 2006, 49:249-260. 
53. Jorgensen LN, Kallehave F, Christensen E, Siana JE, Gottrup F: Less collagen production in smokers. Surgery 1998, 123:450-455.

54. Knuutinen A, Kokkonen N, Risteli J, Vahakangas K, Kallioinen M, Salo T, Oikarinen A: Smoking affects collagen synthesis and extracellular matrix turnover in human skin. Br J Dermatol 2002, 146:588-594.

55. Castillo RC, Bosse MJ, MacKenzie EJ, Patterson BM: Impact of smoking of fracture healing and risk of complications in limb-threatening open tibia fractures. J Orthop Trauma 2005, 19:151-157.

56. Raikin SM, Landsman JC, Alexander VA, Froimson MI, Plaxton NA: Effect of nicotine on the rate and strength of long bone fracture healing. Clin Orthop 1998, 353:231-237.

57. Chen F, Osterman L, Mahony K: Smoking and bony union after ulnashorting osteotomy. Am J Orthop 2001, 30:486-489.

58. Karim A, Pandit H, Murray J, Wandless F, Thomas NP: Smoking and reconstruction of the anterior cruciate ligament. J Bone Jt Surg (Br) 2006, 88:1027-1031.

59. Gill CS, Sandell LJ, El-Zawawy HB, Wright RW: Effects of cigarette smoking on early medial collateral ligament healing in a mouse model. $J$ Orth Res 2006, 24:2141-2149.

60. Schaffer M, Barbul A: Lymphocyte function in wound healing and following injury. Br J Surg 1998, 85:444-460

61. Barbul A, Regan MC: Immune involvement in wound healing. Otolaryngol Clin North Am 1995, 28:955-968.

62. Di Pietro LA: Wound healing: the role of macrophages and other immune cells. Shock 1995, 4:233-240.

63. Park JE, Barbul A: Understanding the role of immune regulation in wound healing. Am J Surg 2004, 187(Suppl 1):11S-16S.

64. Lando HA, Haddock CK, Klesges RC, Talcott GW, Jensen J: Smokeless tobacco use in a population of young adults. Addict Behav 1999, 24:431-447.

65. Di Franza JR, Winters TH, Goldberg RJ, Cirillo L, Biliouris T: The relationship of smoking to motor vehicle accidents and traffic violations. NY State J Med 1986, 86:464-467.

66. Eiser JR, Sutton SR: Smoking, seat belts, and beliefs about health. Addict Behav 1979, 4:331-338.

67. Chiolero A, Wietlisbach V, Ruffieux C, Paccaud F, Cornuz J: Clustering of risk behaviors with cigarette consumption: a population-based survey. Prev Med 2006, 42:348-353.

68. Suchi M, Matsuki H, Misawa K, Kasuga H, Yanagisawa Y: The effect of abstinence from smoking on urinary excretion of hydroproline. Tokai J Exp Clin Med 1989, 14:401-407.

69. Tollerud DJ, Clarke JW, Brown LM, Neuland CY, Mann DL, Pankiw-Trost LK, Blattner WA, Hoover RN: Association of cigarette smoking with decreased numbers of circulating natural killer cells. Am Rev Resp Dis 1989, 139:194-198

70. Hersey P, Prendergast D, Edwards A: Effects of cigarette smoking on the immune system. Med J Aust 1983, 2:425-429.

71. Miller $L G$, Goldstein $G$, Murphy M, Ginns LC: Reversible alterations in immunoregulatory T Cells in smoking. Chest 1982, 82:526-529.

72. Yarnell JWG, Sweetnam PM, Rogers S, Elwood PC, Bainton D, Baker IA, Esatham $\mathrm{R}$, Etherington MD: Some long term effects of smoking from the Caerphilly and Speedwell Collaborative Surveys. J Clin Pathol 1987, 40:909-913.

73. Friedman GD, Siegelaub AB, Seltzer CC, Feldman R, Collen MF: Smoking habits and the leukocyte count. Arch Environ Health 1973, 26:137-143.

74. Hughes DA, Haslam PL, Townsend PJ, Turner-Warwick M: Numerical and functional alterations in circulatory lymphocytes in cigarette smokers. Clin Exp Immunol 1985, 61:459-466.

75. Nobel RC, Penny BB: Comparison of leukocyte count and function in smoking and nonsmoking men. Infect Immun 1975, 12:550-555.

76. Gardner LI, Dziados JE, Jones BH, Brundage JF, Harris JM, Sullivan R, Gill P: Prevention of lower extremity stress fractures: a controlled trial of a shock absorbent insole. Am J Public Health 1988, 78:1563-1567.

77. Shaffer RA, Brodine SK, Almeida SA, Williams KM, Ronaghy S: Use of simple measures of physical activity to predict stress fractures in young men undergoing a rigorous physical training program. Am J Epidemiol 1999, 149:236-242.

78. Kohrt WM, Bloomfield SA, Little KD, Nelson ME, Yingling VR: Physical activity and bone health. Position stand of the American College of Sports Medicine. Med Sci Sports Exerc 2004, 36:1985-1996.

79. Layne JE, Nelson ME: The effects of progressive resistance training on bone density: a review. Med Sci Sports Exerc 1999, 31:25-30.

80. Maffulli N, King JB: The effects of physical activity on some components of the skeletal system. Sports Med 1992, 13:393-407.
81. Blair SN, Cheng Y, Holder JS: Is physical activity or physical fitness more important in defining health benefits? Med Sci Sports Exerc 2001, 33:S379-S399.

82. Kell RT, Bell G, Quinney A: Musculoskeletal fitness, health outcomes and quality of life. Sports Med 2001, 31:863-873.

83. Afghani A, Xie B, Wiswell RA, Gong J, Li Y, Johnson CA: Bone mass of Asian adolescents in China: influence of physical activity and smoking. Med Sci Sports Exerc 2003, 35:720-729.

84. Babaroutsi E, Magkos F, Manios Y, Sidossis LS: Lifestyle factors affecting heel ultrasound in Greek females across different life stages. Osteoporosis Int 2005, 16:552-561.

85. Knapik JJ, Darakjy S, Hauret KG, Canada S, Scott S, Rieger W, Marin R, Jones $\mathrm{BH}$ : Increasing the physical fitness of low fit recruits before Basic Combat Training: an evaluation of fitness, injuries and training outcomes. Mil Med 2006, 171:45-54

86. Knapik JJ, Trone DW, Swedler DI, Villasenor A, Bullock SH, Schmied E, Brockelman $T$, Han $P$, Jones BH: Injury reduction effectiveness of assigning running shoes based on plantar shape in Marine Corps basic training Am J Sports Med 2010, 38:1759-1767.

87. Knowles SB, Marshall SW, Bowling JM, Loomis D, Millikan R, Yang J, Weaver NL, Kalsbeek W, Miller FO: A prospective study of injury incidence among North Carolina high school athletes. Am J Epidemiol 2006, 164:1209-1221.

88. Macera CA, Pate RR, Powell KE, Jackson KL, Kendrick JS, Craven TE: Predicting lower-extremity injuries among habitual runners. Arch Int Med 1989, 149:2565-2568.

89. Marti B, Vader JP, Minder CE, Abelin T: On the epidemiology of running injuries. The 1984 Bern Grand-Prix study. Am J Sports Med 1984, 1988(16):285-294.

90. VanMechelen W, Twisk J, Molendijk A, Blom B, Snel J, Kemper HC: Subjectrelated risk factors for sports injuries: a 1-yr prospective study in young adults. Med Sci Sports Exerc 1996, 28:1171-1179.

91. Orchard JW: Intrinsic and extrinsic risk factors for muscle strains in Australian football. Am J Sports Med 2001, 29:300-303.

92. Voaklander DC, Saunders LD, Quinney HA: Personal risk factors for injury in recreational and old-timer ice hockey. Sports Med Training Rehabil 1998, 8:239-250.

93. Silder A, Heiderscheit BC, Thelen DG, Enright T, Tuite MJ: MR observation of long-term musculoskeletal remodeling following a hamstring strain injury. Skeletal Radiol 2008, 37:1101-1109.

94. Silder $A$, Thelen $D G$, Heiderscheit $B C$ : Effects of prior hanstring injury of strength, flexibility and running mechanics. Clin Biomech 2010, 25(7):681-686.

95. OToole BI: Intellegence and behavior and motor vehicle accident mortality. Accid Anal Prev 1990, 22:211-221.

96. Osler M, Andersen AMN, Laursen B, Lawlor DA: Cognitive function in childhood and early adulthood and injuries later in life: the Metropolit 1953 male birth cohort. Int J Epidemiol 2007, 36:212-219.

97. Whitlock G, Norton R, Clark T, Pledger M, Jackson R, MacMahon S: Motor vehicle driver injury and socioeconomic status: a cohort study with prospective and retrospective driver injury. J Epidemiol Commun Health 2003, 57:512-516.

98. Barreto SM, Swerdlow AJ, Schoemaker MJ, Smith PG: Predictors of nonfatal occupational injury following employment in a Brazilian steelworks. Scand J Work Environ Health 2000, 26:523-528.

99. Babio GO, Daponte-Codina A: Factors associated with seatbelt, helmet, and child safety seat belt use in a Spanish high-risk area. J Trauma 2006 60:620-626.

100. Bullock SH, Jones BH, Gilchrist J, Marshall SW: Prevention of physical training-related injuries: Recommendation for the military and other active populations based on expedited systematic reviews. Am J Prev Med 2010, 18(Supp|1):156-181.

101. Gilchrist J, Jones BH, Sleet DA, Kimsey CD: Exercise-related injuries among women: strategies for prevention from civilian and military studies. Morb Mortal Weekly Rep 2000, 49:13-33.

102. Friedl KE: Body composition and military performance: origins of the Army standards. In Body Composition and Military Performance. Edited by Marriott BM, Grumstrup-Scott J. Washington, DC: National Academy Press; 1992:31-55.

\section{doi:10.1186/1745-6673-8-5}

Cite this article as: Knapik et al:: A prospective investigation of injury incidence and risk factors among army recruits in combat engineer training. Journal of Occupational Medicine and Toxicology 2013 8:5. 